Article

\title{
Transformation of carbon dioxide into valuable chemicals over bifunctional metallosalen catalysts bearing quaternary phosphonium salts
}

\author{
Wuying Zhang a,b, Rongchang Luo a,*, Qihang Xu a, Yaju Chen a, Xiaowei Lin a, Xiantai Zhou c, \\ Hongbing Ji a,\# \\ a School of Chemistry, Key Laboratory of Low-Carbon Chemistry \& Energy Conservation of Guangdong Province, Sun Yat-sen University, Guangzhou \\ 510275, Guangdong, China \\ b School of Applied Chemistry and Biological Technology, Shenzhen Polytechnic, Shenzhen 518055, Guangdong, China \\ c School of Chemical Engineering and Technology, Sun Yat-sen University, Zhuhai 519000, Guangdong, China
}

\section{A R T I C L E I N F}

\section{Article history:}

Received 17 January 2017

Accepted 28 February 2017

Published 5 April 2017

\section{Keywords:}

Carbon dioxide

Salen catalyst

Quaternary phosphonium salt

Cooperative effect

Reaction mechanism

\begin{abstract}
A B S T R A C T
The chemical transformation of $\mathrm{CO}_{2}$ under mild conditions remains a great challenge because of its exceptional kinetic and thermodynamic stability. Two important reactions in the transformation of $\mathrm{CO}_{2}$ are the $\mathrm{N}$-formylation reaction of amines using hydrosilanes and $\mathrm{CO}_{2}$, and the cycloaddition of $\mathrm{CO}_{2}$ to epoxides. Here, we report the high efficiency of bifunctional metallosalen complexes bearing quaternary phosphonium salts in catalyzing both of these reactions under solvent-free, mild conditions without the need for co-catalysts. The catalysts' bifunctionality is attributed to an intramolecular cooperative process between the metal center and the halogen anion. Depending on the reaction, this activates $\mathrm{CO}_{2}$ by permitting either the synergistic activation of $\mathrm{Si}-\mathrm{H}$ bond via metal-hydrogen coordinative bond $(\mathrm{M}-\mathrm{H})$ or the dual activation of epoxide via metal-oxygen coordinative bond (M-O). The one-component catalysts are also shown to be easily recovered and reused five times without significant loss of activity or selectivity. The current results are combined with previous work in the area to propose the relevant reaction mechanisms.
\end{abstract}

(C) 2017, Dalian Institute of Chemical Physics, Chinese Academy of Sciences. Published by Elsevier B.V. All rights reserved.

\section{Introduction}

The development of green chemistry and atom economy approaches and the fact that carbon dioxide $\left(\mathrm{CO}_{2}\right)$ is an inexpensive, highly abundant and renewable $\mathrm{C} 1$ building block, have caused the chemical fixation of $\mathrm{CO}_{2}$ to produce high-added-value chemicals to attract much interest in recent years [1]. A particularly common example is the cycloaddition reaction between $\mathrm{CO}_{2}$ and epoxides to synthesize cyclic car- bonates. This reaction may be facilitated by numerous catalytic systems, including alkali metal halides [2], quaternary onium salts [3], ionic liquids (ILs) [4-6], metal complexes [7], metal oxides [8], metal-organic frameworks (MOFs) [9,10], and porous organic polymers (POPs) [11,12]. Another promising reaction with $\mathrm{CO}_{2}$-its reduction to formamides using amines and hydrosilanes [13] — has also been developed using various catalysts, including organic bases [14], inorganic salts [15,16], strong polar solvents [17], ILs [18], metal complexes [19], and

\footnotetext{
* Corresponding author. Tel: +86-20-84111675; Fax: +86-20-84113654; E-mail: luorongc@mail.sysu.edu.cn

\# Corresponding author. Tel: +86-20-84113658; Fax: +86-20-84113654; E-mail: jihb@mail.sysu.edu.cn

This work was supported by the National Natural Science Foundation of China (21676306, 21425627), the National Key Research and Development Program of China (2016YFA0602900), and the Natural Science Foundation of Guangdong Province (2016A030310211, 2015A030313104). DOI: 10.1016/S1872-2067(17)62802-X| http://www.sciencedirect.com/science/journal/18722067 | Chin. J. Catal., Vol. 38, No. 4, April 2017
} 
$N$-heterocyclic carbenes [20]. Recently, our group reported that one-component $\mathrm{Al}($ salen) complexes with additional imidazolium-based IL moieties catalyzed the $\mathrm{CO}_{2}$ /epoxide cycloaddition reaction under ambient conditions [21,22]. Additionally, the IL-functionalized $\mathrm{Zn}$ (salen) analogues have been shown to promote the $\mathrm{CO}_{2}$-based $\mathrm{N}$-formylation reaction of organic amines to yield formamide derivatives when reacted with hydrosilanes [23].

Analysis of the homogeneous catalytic systems above that involve $\mathrm{CO}_{2}$ (Scheme 1) revealed a dual activation at the metal center (Lewis acid) and at the halogen anion (nucleophile) which may explain the high efficiency [24]. It is possible for the intramolecular cooperative effect to either activate the $\mathrm{Si}-\mathrm{H}$ bond within hydrosilane through a metal-hydrogen coordinative bond $(\mathrm{M}-\mathrm{H})$, or to activate the epoxide through a metal-oxygen coordinative bond (M-0). The highly active intermediates ( $\mathrm{Zn}-\mathrm{H}$ or $\mathrm{Al}-\mathrm{O}$ species) may make the $\mathrm{CO}_{2}$ insertion more favorable, thereby facilitating the activation of $\mathrm{CO}_{2}$. However, when using traditional quaternary ammonium salts as synthetic units instead of imidazolium-based ILs, low catalytic activity was observed, probably because of the poor solubility exhibited by the simple synthetic method when using ethylenediamine as a feedstock [21,23]. Thus, drawing on other work reported in this area $[25,26]$, we envisioned that bifunctional catalysts bearing quaternary phosphonium salts could exhibit better catalytic performance on account of their superior solubility and stability.

Herein, quaternary phosphonium salts were successfully introduced into the framework of a salen ligand at the 3,3'- and 5,5'-positions as shown in Scheme 2. After metalation with $\mathrm{ZnEt}_{2}$ or $\mathrm{AlEt}_{2} \mathrm{Cl}$, the Zn-based catalysts (denoted as 5-PSZ-Cl, 3-PSZ-Cl and 3-PSZ-Br) we describe the novel demonstration of their use as bifunctional catalysts to catalyze the $\mathrm{CO}_{2}$-based $\mathrm{N}$-formylation of amines with hydrosilanes. Meanwhile, the Al-based complexes (denoted as 5-PSA-Cl, 3-PSA-Cl and 3-PSA-Br) are shown to promote the $\mathrm{CO}_{2}$ /epoxide cycloaddition reaction at ambient conditions. Accordingly, such efficient intramolecular cooperative catalysis indicates that $\mathrm{CO}_{2}$ can be
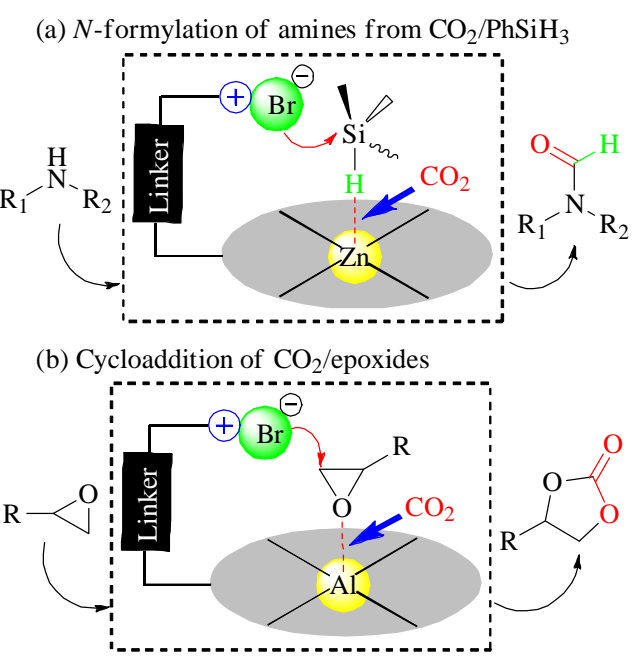

Scheme 1. The dual activation of the metal center and the halogen anion.

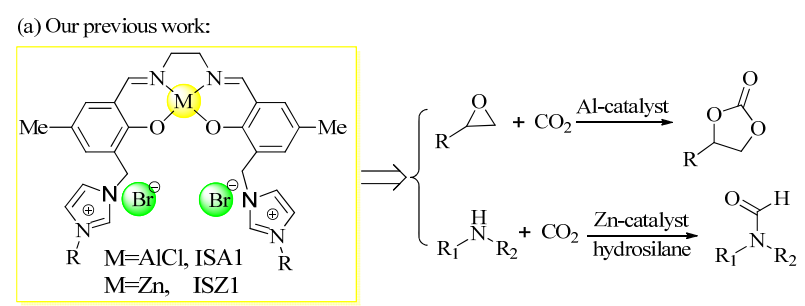

(b) This work:

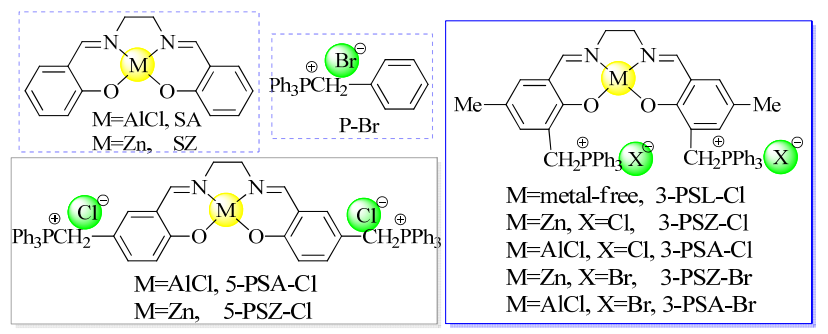

Scheme 2. Bifunctional catalysts developed in (a) previous and (b) the current work.

transformed under mild conditions. The bifunctional metallosalen catalysts are shown to be very active, highly selective, stable, and easily recycled by manipulating the solvent. A kinetic analysis is also carried out to investigate the reaction mechanism and help understand larger scale development of these bifunctional catalysts that are useful for converting $\mathrm{CO}_{2}$.

\section{Experimental}

Propylene oxide, styrene oxide, epichlorohydrin, epibromohydrin, allyl glycidyl ether, $n$-butyl glycidyl ether, iso-propyl glycidyl ether, glycidyl methacrylate, cyclohexene oxide, $\mathrm{N}$-methylaniline, 4-methoxy- $\mathrm{N}$-methylaniline, 4-chloro- $\mathrm{N}$-methylaniline, morpholine, diethylamine, 4-methylpiperidine, 4-phenylpiperidine, diphenylsilane, and poly(methylhydrosiloxane) were obtained from J\&K Scientific Ltd. Phenylsilane was purchased from Energy Chemical Ltd. The corresponding bifunctional catalysts were synthesized according to procedures detailed in our previous work [21-23,27].

The reaction was carried out in a $10-\mathrm{mL}$ stainless steel autoclave which was coupled with a magnetic stirrer. In a typical experiment for the $\mathrm{N}$-formylation of amines with $\mathrm{CO}_{2}$ and hydrosilanes, $N$-methylaniline, the catalyst 3-PSZ-Br (or other catalysts when performing comparisons), and phenylsilane were added into the reactor. Subsequently, $\mathrm{CO}_{2}$ was charged into the reactor until the pressure reached $0.5 \mathrm{MPa}$ and the reactor was then heated by an oil bath to $40{ }^{\circ} \mathrm{C}$ while being stirred continuously. After the reaction, the autoclave was quickly cooled to $0{ }^{\circ} \mathrm{C}$ and depressurized to atmospheric pressure [14]. The cycloaddition reactions with epoxides and $\mathrm{CO}_{2}$ were carried out in a similar fashion. Conversions and yields were determined using naphthalene or biphenyl as the internal standard and measured by a gas chromatograph (GC2010, Shimadzu Corporation, Japan) equipped with a capillary column (Rtx-5, $30 \mathrm{~m} \times 0.32 \mathrm{~mm} \times 0.25 \mu \mathrm{m}$ ) and a flame ionization detector (FID). The structure and the purity of the corresponding products were identified by ${ }^{1} \mathrm{H}$ NMR, ${ }^{13} \mathrm{C}$ NMR, and GC-MS 
analysis.

Larger scale (kinetics) experiments were carried out using an EasyMax ${ }^{\mathrm{TM}} 102$ system (Mettler Toledo, OH, USA) equipped with a 100-mL stainless steel autoclave operated in semi-batch mode with the reaction progress monitored by in situ infrared (IR) spectroscopy [22].

\section{Results and discussion}

\section{1. $\mathrm{N}$-formylation of amines with $\mathrm{CO}_{2}$ and hydrosilanes}

Formamide derivatives are important platform compounds in the chemical industry [28]. Therefore, we first investigated the catalytic performance in the solvent-free $\mathrm{N}$-formylation of amines using $\mathrm{CO}_{2}$ and hydrosilanes as raw materials. On the basis of our previous work [23], it was demonstrated that the $\mathrm{Zn}$ (salen) catalysts bearing additional imidazolium-based IL units exhibited high catalytic efficiency because of the synergistic effect between the $\mathrm{Zn}$ active center and the halogen anions. Accordingly, we supposed that the $\mathrm{Zn}$ (salen) catalysts functionalized by quaternary phosphonium salts might also present similar catalytic performance given their structural features. Therefore, three kinds of the functional $\mathrm{Zn}$ (salen) catalysts were successfully synthesized using the same method as used in the previous work. The simple $\mathrm{Zn}$ (salen) complex (denoted as SZ) was also obtained for comparison.

A loading of $0.5 \mathrm{~mol} \%$ of the catalyst SZ was unable to catalyze the transformation at $40{ }^{\circ} \mathrm{C}$ and $0.5 \mathrm{MPa} \mathrm{CO}_{2}$ pressure even when the the reaction time was extended to $12 \mathrm{~h}$ (Table 1 , entry 2). Low yields $(<5 \%)$ were obtained for 5 -h experiments with the simple catalyst $\mathrm{P}-\mathrm{Br}$ and the simple salen ligand 3-PSL-Br at loadings of $1.0 \mathrm{~mol} \%$ (Table 1, entries 3 and 4). Conversely, the bifunctional catalyst 3-PSZ-Br exhibited excellent catalytic activity and a 96\% yield under identical conditions (Table 1, entry 5). Extending the reaction time to $6 \mathrm{~h}$ for the homogeneous catalytic system increased the conversion and chemoselectivity to $>99 \%$, still under mild conditions (Table 1, entry 6). The catalytic performance of Cl-based 3-PSZ-Cl was slightly inferior to that of Br-based 3-PSZ-Br (Table 1, entry 7 vs entry 5), especially during the later stages of the reaction (as shown in the kinetic results presented in Fig. 1). We suggest that the difference may be caused by the nucleophilicity of the halogen anion, which is crucial for the activation of $\mathrm{Si}-\mathrm{H}$ bond in hydrosilanes [29]. The $\mathrm{Zn}$ (salen) catalyst 5-PSZ-Cl that was functionalized by the quaternary phosphonium salts at the 5,5'-position of the salen ligand exhibited a lower catalytic performance than that of the same catalyst functionalized at the 3,3'-position (Table 1, entry 8 vs entry 5). This implied that these bifunctional catalysts required a specific spatial structure to actively catalyze the reduction of $\mathrm{CO}_{2}$. The $\mathrm{N}$-formylation of amine with $\mathrm{CO}_{2}$ under the same reaction conditions was found to depend on the inherent structure of the hydrosilane (Table 1, entries 9 and 10), with either $\mathrm{Ph}_{2} \mathrm{SiH}_{2}$ or polymethylhydrosiloxane (PMHS) being observed as an unreactive reductant because of steric or electronic effects [16]. Interestingly, the performance of 3-PSZ-Br was better than that

\section{Table 1}

Results of the $\mathrm{N}$-formylation reaction of $\mathrm{N}$-methylaniline with $\mathrm{CO}_{2}$ and hydrosilanes.

\begin{tabular}{|c|c|c|c|c|c|}
\hline Entry & Catalyst & $\begin{array}{l}\text { Hydrosilane } \\
(\mathrm{mmol})\end{array}$ & $t(\mathrm{~h})$ & $\begin{array}{c}\text { Conversion }^{\mathrm{a}} \\
(\%)\end{array}$ & $\begin{array}{c}\text { Yield a }^{\text {a }} \\
(\%)\end{array}$ \\
\hline 1 & - & $\mathrm{PhSiH}_{3}(1.0)$ & 24 & - & - \\
\hline 2 & SZ & $\mathrm{PhSiH}_{3}(1.0)$ & 12 & $<1$ & $<1$ \\
\hline 3 & $\mathrm{P}-\mathrm{Br}$ & $\mathrm{PhSiH}_{3}(1.0)$ & 5 & 5 & $<5$ \\
\hline 4 & 3-PSL-Br & $\mathrm{PhSiH}_{3}(1.0)$ & 5 & 5 & $<5$ \\
\hline 5 & 3-PSZ-Br & $\mathrm{PhSiH}_{3}(1.0)$ & 5 & 96 & 96 \\
\hline 6 & 3-PSZ-Br & $\mathrm{PhSiH}_{3}(1.0)$ & 6 & $>99$ & 99 \\
\hline 7 & 3-PSZ-Cl & $\mathrm{PhSiH}_{3}(1.0)$ & 5 & 83 & 83 \\
\hline 8 & 5-PSZ-Cl & $\mathrm{PhSiH}_{3}(1.0)$ & 5 & 68 & 68 \\
\hline 9 & 3-PSZ-Br & $\mathrm{Ph}_{2} \mathrm{SiH}_{2}(1.0)$ & 6 & $<1$ & $<1$ \\
\hline 10 & 3-PSZ-Br & PMHS (1.0) & 6 & $<1$ & $<1$ \\
\hline $11^{\mathrm{b}}$ & ISZ1 & $\mathrm{PhSiH}_{3}(1.0)$ & 6 & 88 & 88 \\
\hline
\end{tabular}

Reaction conditions: 10 -mL stainless-steel autoclave, $N$-methylaniline 1 mmol, catalyst $0.01 \mathrm{mmol}, 40^{\circ} \mathrm{C}, \mathrm{CO}_{2}$ pressure $0.5 \mathrm{MPa}$.

${ }^{a}$ Determined by GC using naphthalene as the internal standard.

${ }^{\mathrm{b}}$ From previous work [23].

of the imidazolium-based ILs ILZ1 reported previously under identical conditions (Table 1, entry 11 vs entry 5). This may be caused by the strong leaving-ability of the halogen anion for the current catalysts. Overall the bifunctional catalyst system was shown to catalyze the $\mathrm{N}$-formylation of amine with $\mathrm{PhSiH}_{3}$ through the reduction of $\mathrm{CO}_{2}$ thanks to the cooperative effect between the zinc active center and the bromide anion.

To analyze the range of substrates, the $N$-formylation reaction was carried out with a range of primary and secondary amines (and $\mathrm{CO}_{2}$ and $\mathrm{PhSiH}_{3}$ ) over 3-PSZ-Br under the same reaction conditions $\left(40{ }^{\circ} \mathrm{C}, 0.5 \mathrm{MPa} \mathrm{CO}_{2}\right.$ ). The results (Table 2) demonstrate the generality of the bifunctional catalytic system. Aromatic, alicyclic and aliphatic amines afforded moder-

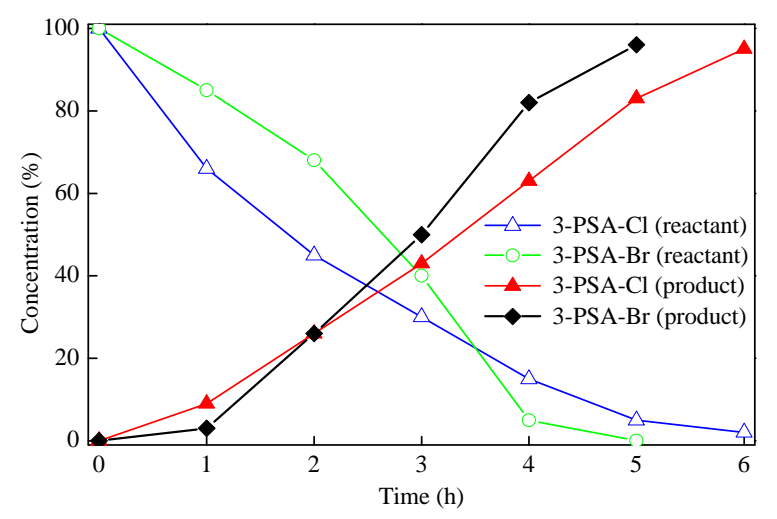

Fig. 1. Change in the concentration of reactant $\left(\mathrm{PhSiH}_{3}\right)$ and product ( $N$-methylformanilide) with time using 3-PSZ-Cl or 3-PSZ-Br as the catalyst. Reaction conditions: $N$-methylaniline $1.0 \mathrm{mmol}, \mathrm{PhSiH}_{3} 1.0$ mmol, catalyst loading $1.0 \mathrm{~mol} \%, \mathrm{CO}_{2}$ pressure $0.5 \mathrm{MPa}, 40{ }^{\circ} \mathrm{C}$. 
Table 2

Results of $\mathrm{N}$-formylation of various amines to produce formamides from $\mathrm{CO}_{2}$ and hydrosilanes over the 3-PSZ-Br catalyst.

Entry (\%)

Reaction conditions: $10-\mathrm{mL}$ autoclave, amine $1.0 \mathrm{mmol}, \mathrm{PhSiH}_{3} 1.0$ mmol, $\mathrm{CO}_{2}$ pressure $0.5 \mathrm{MPa}, 3-\mathrm{PSZ}-\mathrm{Br}$ loading $1.0 \mathrm{~mol} \%, 40{ }^{\circ} \mathrm{C}, 6 \mathrm{~h}$.

ate-to-excellent yields and excellent chemoselectivities [30]. Both steric and electronic effects were thought to have played an important role in the $\mathrm{N}$-formylation of amines. For example, the yields obtained from $N$-methylaniline derivatives with electron-donating groups at the para-position of the phenyl group were generally lower than those with para electron-withdrawing groups under identical conditions (i.e., methoxyl > hydrogen $>$ chloride, see Table 2, entries 1-3). Notably, the mono- and di-formylated formamides were obtained for most of the primary amines with two active $\mathrm{N}-\mathrm{H}$ bonds (Table 2, entries 10 and 11) [18]. In summary, the bifunctional $\mathrm{Zn}$ (salen) catalysts exhibited excellent substrate compatibility.

\subsection{Cycloaddition reaction between $\mathrm{CO}_{2}$ and epoxides}

Cyclic carbonates were widely used as electrolyte components in lithium batteries, polar aprotic solvents, and intermediates in the production of pharmaceuticals and fine chemicals. Generally speaking, the cycloaddition reaction between $\mathrm{CO}_{2}$ and epoxides is regarded as a promising and 'greener' alternative to the traditional phosgene $\left(\mathrm{COCl}_{2}\right)$ and carbon monoxide (CO) production process. We previously proposed a mechanism that details the dual activation of epoxides through a cooperative effect between an active metal center and a nucleophile [21]. To further understand the bifunctionality of the cat- alysts studied here, we also investigated their use in the cycloaddition reaction between $\mathrm{CO}_{2}$ and allyl glycidyl ether (AGE) to afford allyl glycidyl carbonate (AGC). The results from reactions operated in a semi-continuous mode under mild, solvent-free conditions are shown in Table 3.

No reaction occurred when the traditional Al(salen) complex (denoted as SA) was used as the sole catalyst (Table 3, entry 1). In 2007, He and coworkers [31] reported that polyethylene glycol-functionalized phosphonium halide could catalyze the transformation of $\mathrm{CO}_{2}$ because of liner effects. Nevertheless, both the simple quaternary phosphonium salts $\mathrm{P}-\mathrm{Br}$ (1.0 mol\%) and the simple salen ligand 3-PSA-Br (0.5 mol\%) were unable to catalyze the cycloaddition reaction after $2.5 \mathrm{~h}$ at $100{ }^{\circ} \mathrm{C}$ and a $\mathrm{CO}_{2}$ pressure of $2.0 \mathrm{MPa}$ (Table 3, entries 2 and 3). Combining the catalysts using a molar ratio of $1: 2$ to give a binary catalytic system produced an AGC yield of $25 \%$ under identical conditions thanks to the intermolecular synergistic effect between the aluminum cation and the bromide anion (Table 3, entry 4). These promising results encouraged us to synthesize bifunctional $\mathrm{Al}($ salen) catalysts bearing quaternary phosphonium salts. Making use of the intramolecular cooperative effect, three kinds of Al-based bifunctional catalysts were successfully prepared and gave high yields (the mechanisms of which are shown in Scheme 1). A loading of $0.5 \mathrm{~mol} \% 3-\mathrm{PSA}-\mathrm{Br}$ efficiently catalyzed the cycloaddition reaction under the same conditions to produce a $97 \%$ yield without adding any co-catalyst (Table 3, entry 5). Regrettably, under the same conditions the two other bifunctional catalysts (5-PSA-Cl and 3-PSA-Cl) presented low catalytic activity for structural reasons

\section{Table 3}

Results of the cycloaddition reaction between $\mathrm{AGE}$ and $\mathrm{CO}_{2}$ using various catalysts.

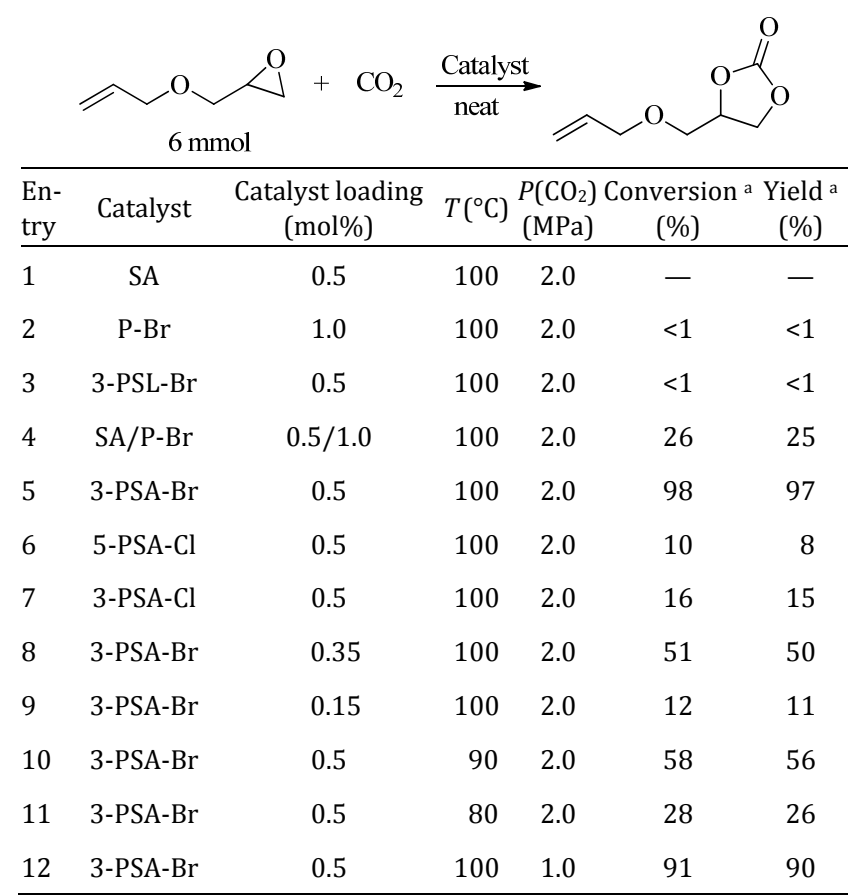

Reaction conditions: 10-mL stainless-steel autoclave, AGE 6 mmol, 2.5 h.

a Determined by GC using biphenyl as the internal standard. 
and because of the poor nucleophilicity of the chloride anion (Table 3, entries 6 and 7). Decreasing the catalyst loading of 3 -PSA-Br to $0.35 \mathrm{~mol} \%$ gave a moderate yield of $51 \%$ (Table 3 , entry 8) while decreasing the loading further to $0.15 \mathrm{~mol} \%$ further decreased the yield (Table 3, entry 9). Decreasing the reaction temperature from 100 to 90 and to $80{ }^{\circ} \mathrm{C}$ caused the the ACG yield to fall sharply from $97 \%$ to $56 \%$ and to $26 \%$, respectively (Table 3, entry 5 vs entries 10 and 11). However, the AGC yield changed only slightly when the $\mathrm{CO}_{2}$ pressure was halved from 2.0 to $1.0 \mathrm{MPa}$ (Table 3, entry 12 vs entry 5).

Subsequently, a variety of terminal epoxides, including glycidyl ether with various functional groups, styrene oxide (SO), epichlorohydrin (ECH), epibromohydrin (EBH), and aliphatic epoxides, were evaluated using a low $(0.5 \mathrm{~mol} \%)$ loading of 3-PSA-Br under relatively mild $\left(100{ }^{\circ} \mathrm{C}, 2.0 \mathrm{MPa} \mathrm{CO}_{2}\right)$, solvent-free conditions. Table 4 shows that the desired cyclic carbonates were exclusively produced from the investigated terminal epoxides in reactions that exhibited good-to-excellent yields and excellent chemoselectivities (Table 4, entries 1-9). Both steric and electronic effects played an important role in determining the success of the reaction. For example, the activity of the epoxides decreased as their alkyl length increased. Similar yields were obtained when the reaction time was ex-

Table 4

Results of the cycloaddition of $\mathrm{CO}_{2}$ to various epoxide substrates over 3-PSA-Br.

\begin{tabular}{lllll} 
Entry Substrate & $\begin{array}{c}\text { Conversion a } \\
(\%)\end{array}$ & $\begin{array}{c}\text { Yield b } \\
(\%)\end{array}$ \\
\hline
\end{tabular}

Reaction conditions: 10-mL stainless-steel autoclave, epoxide $6 \mathrm{mmol}$, 3-PSA-Br loading $0.03 \mathrm{mmol}, \mathrm{CO}_{2}$ pressure $2.0 \mathrm{MPa}, 100{ }^{\circ} \mathrm{C}$. a Product identification via FT-IR, ${ }^{1} \mathrm{H}$ NMR, ${ }^{13} \mathrm{C}$ NMR, and GC-MS. b Determined by GC. tended (Table 4, entry 2 vs entry 3 and entry 6 vs entry 7). The low activity with cyclohexene oxide (an internal epoxide that is known to be a challenging substrate in this reaction [32]) was probably caused by a high degree of steric hindrance (Table 4, entry 10). Overall, the bifunctional catalyst exhibited excellent tolerance to the various (alkyl, phenyl, alkenyl, halogen, ether, and alkoxy) functional groups, demonstrating its applicability to a wide range of industrial uses [33].

\subsection{Recyclability}

We analyzed the recyclability of 3-PSA-Br (chosen for its special solubility) using AGE as the model substrate under mild conditions $\left(100{ }^{\circ} \mathrm{C}, 2.0 \mathrm{MPa} \mathrm{CO}_{2}\right)$. After adding ethyl acetate or ethyl ether to the reaction mixture, the bifunctional catalyst was easily separated for use in the next cycle. The results in Fig. 2 show that the recycled 3-PSA-Br still presented high activity with yields of up to $90 \%$ and ACG selectivity of approximately $95 \%$. This suggests that manipulating the solvent can permit 3-PSA-Br to take part in "one-phase catalysis and two-phase separation" [21].

\subsection{Kinetic investigation}

The catalytic performance described above was caused by a cooperative effect between the active metal center and the halogen anion. To further understand the intramolecular synergistic catalysis of the $\mathrm{Al}($ salen) complexes functionalized by quaternary phosphonium salts, a larger scale investigation was conducted for the cycloaddition of $\mathrm{CO}_{2}$ to epoxides using 3-PSA-Br as the sole catalyst. Styrene oxide (SO) was chosen as the representative substrate for the large-scale synthesis of styrene cyclic carbonate (SC).

The in situ IR spectra results (Fig. 3) showed an increase in the intensity of the characteristic peaks at 1159 and $1065 \mathrm{~cm}^{-1}$ (C-0), and $1810 \mathrm{~cm}^{-1}(\mathrm{C}=0)$. Meanwhile, a decrease was observed in the intensity of the peak around $816 \mathrm{~cm}^{-1}$, which was attributed to vibrations of the epoxy ring skeleton and was used to monitor the degree of conversion and yields [34]. An SC yield of $>85 \%$ was obtained after $20 \mathrm{~h}$ when using a modest

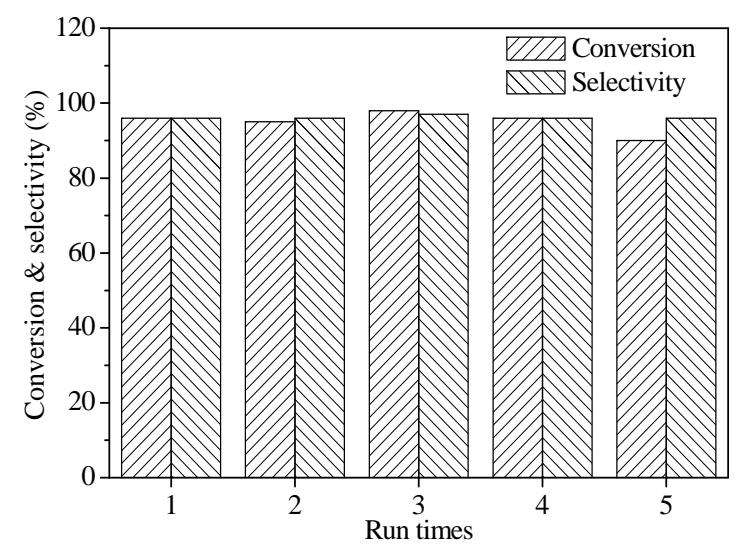

Fig. 2. Recyclability of 3-PSA-Br used for the coupling of AGE with $\mathrm{CO}_{2}$. 

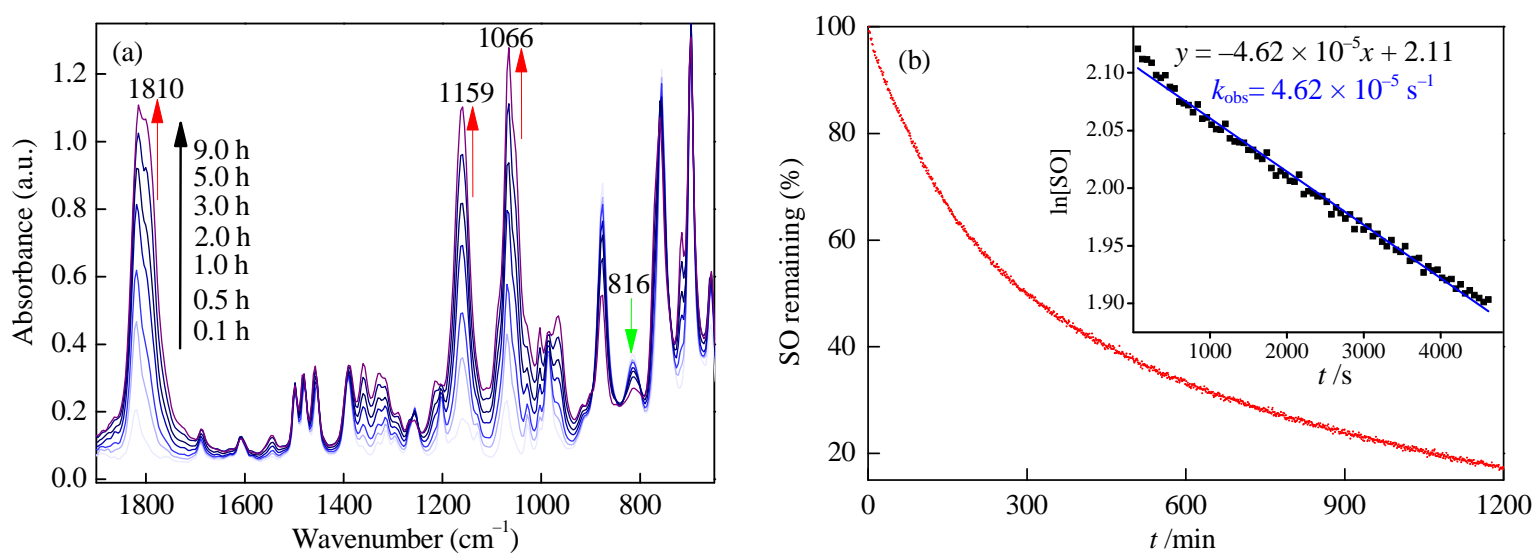

Fig. 3. (a) In situ IR spectra during reaction and (b) change in SO content over time and (inset) plot to obtain observed rate constant. Reaction conditions: 100 -mL stainless-steel autoclave, SO $350 \mathrm{mmol}, \mathrm{CO}_{2}$ pressure $2.0 \mathrm{MPa}, 100{ }^{\circ} \mathrm{C}$, catalyst loading $0.05 \mathrm{~mol} \%$.

amount of $(0.05 \mathrm{~mol} \%)$ at mild $\left(100{ }^{\circ} \mathrm{C}\right.$ and $\left.2.0 \mathrm{MPa} \mathrm{CO} 2\right)$, solvent-free conditions. The observed rate constant ( $k_{\mathrm{obs}}$ ) of $4.62 \times 10^{-5} \mathrm{~s}^{-1}$ was determined from the slope of a linear plot of the natural logarithm of the changing sample concentration $(\ln [\mathrm{SO}])$ against time $(t)$. The results indicated that a selectivity of $99 \%$ was achievable in this larger-scale production (Fig. 3) [22].

The kinetic experiments for the 3-PSA-Br-catalyzed cycloaddition reaction were carried out on the basis of the steady-state approximation method we have detailed previously [22]. Using the Arrhenius equation, the activation energy can be calculated from the relationship between $k_{\text {obs }}$ and the absolute temperature $(T)$. Therefore, an activation energy of $67.7 \mathrm{~kJ} / \mathrm{mol}$ was determined as a function of the reaction temperature in the range $60-90^{\circ} \mathrm{C}$ by fitting the data from a plot of the natural logarithm of the observed pseudo-first-order rate constant $\left(\ln \left[k_{\text {obs }}\right]\right)$ against the reciprocal of the absolute temperature (1/T) (Fig. 4) [35]. Compared with values reported

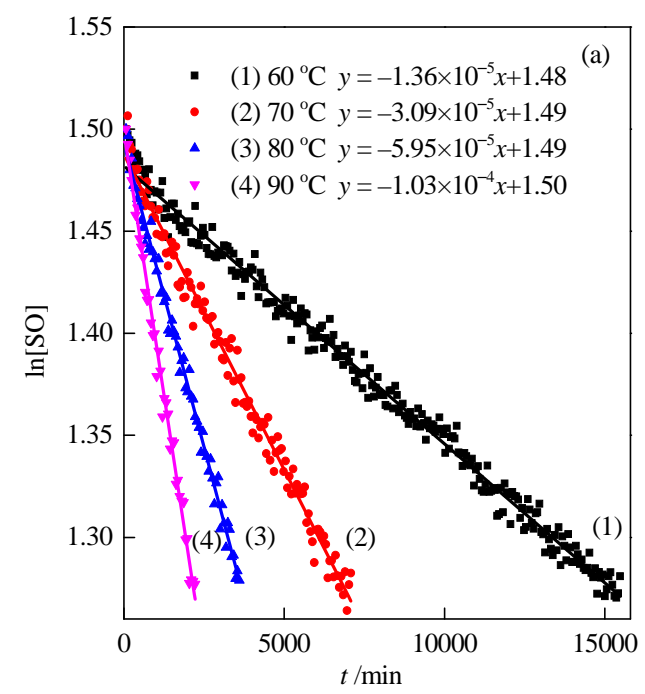

elsewhere, this lower activation energy appeared characteristic of the excellent catalytic activity observed under relatively mild conditions. The kinetic data were also analyzed by fitting a line to a plot of the natural logarithm of the observed pseudo-first-order rate constant $\left(\ln \left[k_{\mathrm{obs}}{ }^{\prime}\right]\right)$ against the natural logarithm of the catalyst concentrations $(\ln [\mathrm{CAT}])$. The corresponding double logarithmic plot had a slope of 1.04, further suggesting that the reaction was first-order for the bifunctional catalyst (Fig. 5) [36], and indicating that the catalytic system followed a monometallic reaction mechanism [22].

\subsection{Reaction mechanisms}

In the $\mathrm{N}$-formylation reaction of amine with $\mathrm{PhSiH}_{3}$ and $\mathrm{CO}_{2}$ over 3-PSZ-Br, the cooperative effect between the zinc center and the bromide anion activates the $\mathrm{Si}-\mathrm{H}$ bond of $\mathrm{PhSiH}_{3}$ [23]. This affords the highly active zinc-hydrogen $(\mathrm{Zn}-\mathrm{H})$ species and permits a mechanism that involves the transi-

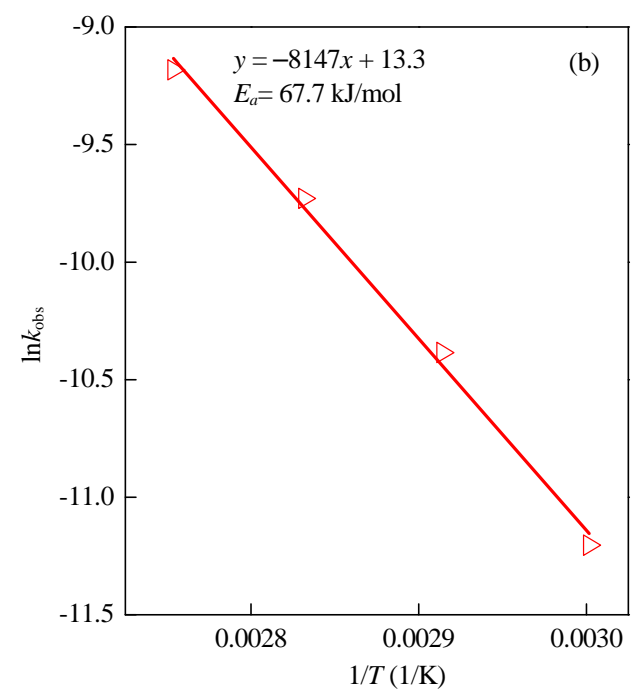

Fig. 4. (a) Decrease in SO concentration ([SO $\left.]_{0}=4.0 \mathrm{~mol} / \mathrm{L}\right)$ with time using a catalyst loading of $3-\mathrm{PSA}-\mathrm{Br}$ in $\mathrm{PC}(20 \mathrm{~g})$ at $2.0 \mathrm{MPa} \mathrm{CO}{ }_{2}$ over the temperature range $60-90^{\circ} \mathrm{C}$; (b) Linear fit to a plot of the natural logarithm of the observed pseudo-first-order rate constant (ln[ $\left.k_{\mathrm{obs}}\right]$ ) against the reciprocal of the absolute temperature $(1 / T)$. 

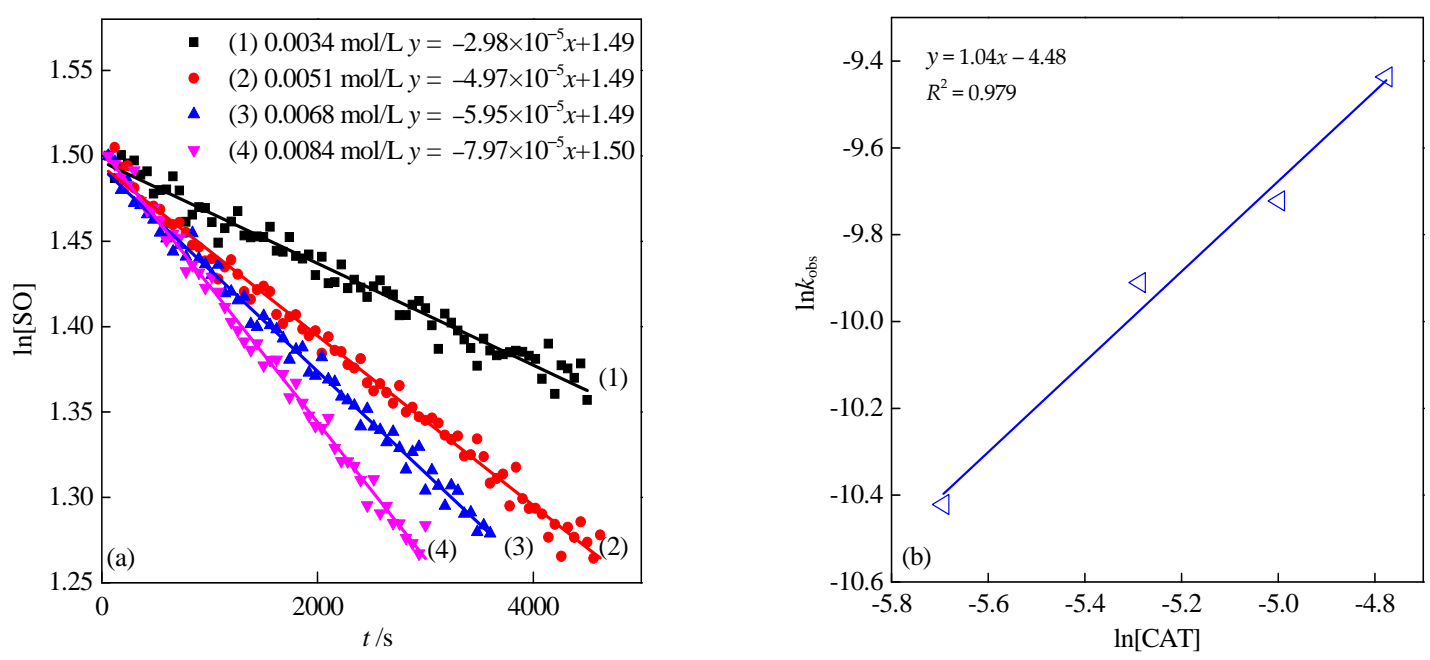

Fig. 5. (a) Decrease in SO concentration ( $\left.[\mathrm{SO}]_{0}=4.0 \mathrm{~mol} / \mathrm{L}\right)$ with time for different catalyst loadings of 3-PSA-Br $(0.0034-0.0084 \mathrm{~mol} / \mathrm{L}) \mathrm{in} \mathrm{PC}(20 \mathrm{~g})$ at $80^{\circ} \mathrm{C}$ and $2.0 \mathrm{MPa} \mathrm{CO}_{2}$; (b) Linear fit to a plot of the natural logarithm of the observed pseudo-first-order rate constant (ln[ $\left.\left.k_{\mathrm{obs}}\right]\right)$ against the natural logarithm of the catalyst concentration $(\ln [\mathrm{CAT}])$.

tion-metal-promoted hydride transfer from $\mathrm{PhSiH}_{3}$ to $\mathrm{CO}_{2}$, based on an intermediate silyl formate [29]. In other words, $\mathrm{PhSiH}_{3}$ can be activated to react with $\mathrm{CO}_{2}$ to yield formoxysilane [37]. The organic amines can also be activated by the bifunctional catalyst 3-PSZ-Br via the hydrogen bond (as determined by ${ }^{1} \mathrm{H}$ NMR spectra), with the corresponding formamides then obtained via the nucleophilic reaction (Scheme 3(a)) [38].

Drawing on our previous work on the cycloaddition reaction between epoxides and $\mathrm{CO}_{2}$, we propose the mechanism illustrated in Scheme 3(b) [21,22]. The aluminum center and bromide ion of these bifunctional catalysts promote an intramolecular synergistic catalysis process that was applicable to the $\mathrm{CO}_{2}$ /epoxide cycloaddition reaction. The epoxide was activated by the Lewis-acidic metal center of 3-PSA-Br, and subsequently attacked by the nucleophile (halogen anion). The metal-oxygen (alkoxide) intermediate could be afforded via the ring-opening of the epoxide [39], which made the insertion of $\mathrm{CO}_{2}$ more favorable and facilitated the activation of $\mathrm{CO}_{2}$. The intramolecular ring-closing reaction then resulted in the formation of cyclic

(a) $N$-formylation with $\mathrm{CO}_{2}$ and $\mathrm{PhSiH}_{3}$

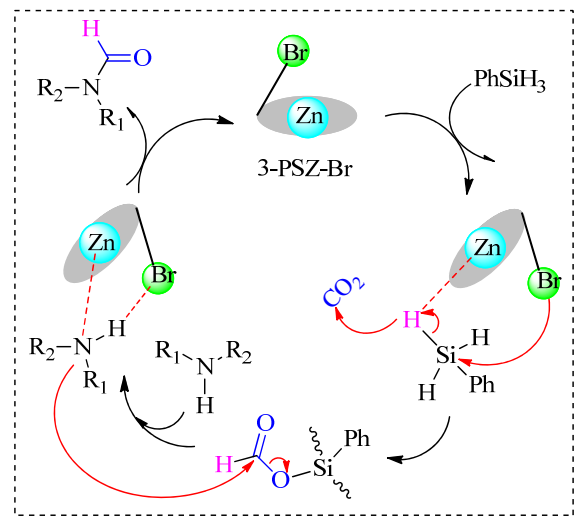

carbonate and the regeneration of the catalyst [40].

\section{Conclusions}

Synthesized metallosalen catalysts bearing quaternary phosphonium salts (3-PSA-Br and 3-PSZ-Br) were successfully applied to the two important reactions: the $\mathrm{CO}_{2}$ /epoxide cycloaddition reaction; and the $\mathrm{N}$-formylation of amine with $\mathrm{PhSiH}_{3}$ and $\mathrm{CO}_{2}$. In both situations, the catalyst exhibited excellent performance and selectivity under mild, solvent-free conditions. No co-catalysts were required; instead, an intramolecular cooperative effect between the active metal center and the halogen anion was responsible for the catalysts' activity. An investigation into the reaction kinetics and mechanism were carried out to better understand the novel properties of the actions of these catalysts in organic reactions with $\mathrm{CO}_{2}$.

\section{References}

[1] Q. Liu, L. P. Wu, R. Jackstell, M. Beller, Nat. Commun., 2015, 6,

(b) Cycloaddition from epoxide and $\mathrm{CO}_{2}$

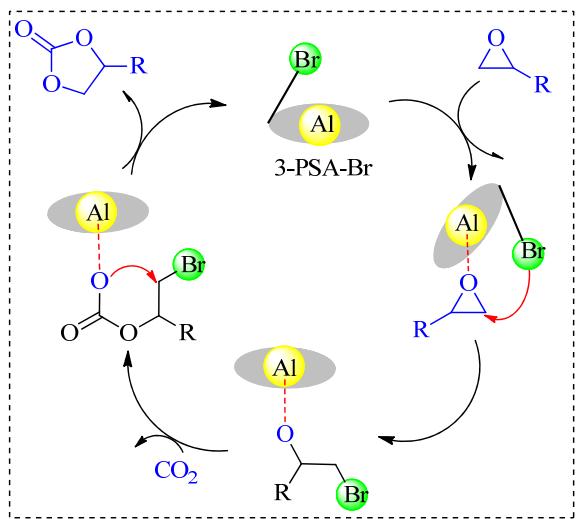

Scheme 3. Proposed mechanisms for (a) the $\mathrm{N}$-formylation of amines with $\mathrm{CO}_{2}$ and $\mathrm{PhSiH}_{3}$ over 3-PSZ-Br and (b) the cycloaddition of $\mathrm{CO}_{2}$ to epoxides over 3-PSA-Br. 


\section{Graphical Abstract}

Chin. J. Catal., 2017, 38: 736-744 doi: 10.1016/S1872-2067(17)62802-X

Transformation of carbon dioxide into valuable chemicals over bifunctional metallosalen catalysts bearing quaternary phosphonium salts

Wuying Zhang, Rongchang Luo*, Qihang Xu, Yaju Chen, Xiaowei Lin, Xiantai Zhou, Hongbing Ji ${ }^{\#}$ Sun Yat-sen University; Shenzhen Polytechnic

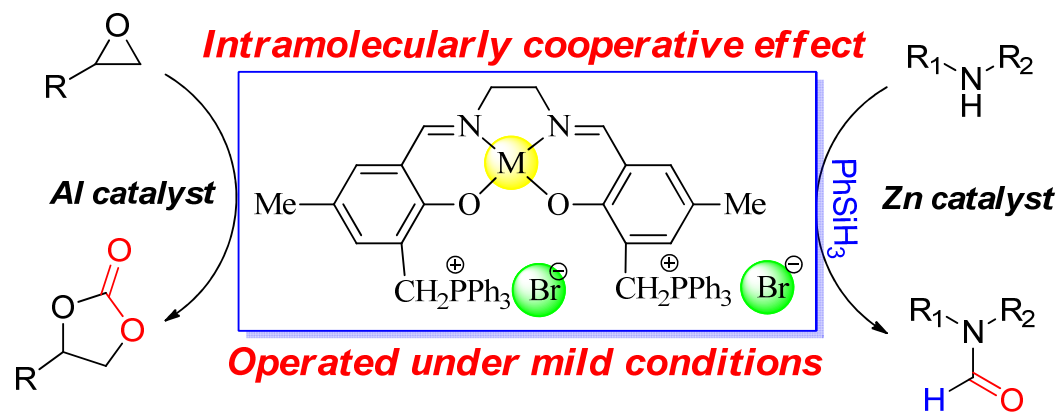

The use of bifunctional metallosalen complexes bearing quaternary phosphonium salts under solvent-free, mild conditions without co-catalysts exhibited high efficiencies catalyzing both the $\mathrm{CO}_{2}$-based $\mathrm{N}$-formylation reaction of amines from hydrosilanes and the cycloaddition of $\mathrm{CO}_{2}$ to epoxides.

5933.

[2] J. W. Comerford, I. D. V. Ingram, M. North, X. Wu, Green Chem., 2015, 17, 1966-1987.

[3] G. Fiorani, W. S. Guo, A. W. Kleij, Green Chem., 2015, 17, 1375-1389.

[4] B. H. Xu, J. Q. Wang, J. Sun, Y. Huang, J. P. Zhang, X. P. Zhang, S. J. Zhang, Green Chem., 2015, 17, 108-122.

[5] T. Chang, X. R. Gao, L. Bian, X. Y. Fu, M. X. Yuan, H. W. Jing, Chin. J. Catal., 2015, 36, 408-413.

[6] M. Y. Wang, R. Ma, L. N. He, Sci. China Chem., 2016, 59, 507-516.

[7] A. Decortes, A. M. Castilla, A. W. Kleij, Angew. Chem. Int. Ed., 2010, 49, 9822-9837.

[8] K. Yamaguchi, K. Ebitani, T. Yoshida, H. Yoshida, K. Kaneda, J. Am. Chem. Soc., 1999, 121, 4526-4527.

[9] C. M. Miralda, E. E. Macias, M. Q. Zhu, P. Ratnasamy, M. A. Carreon, ACS Catal., 2012, 2, 180-183.

[10] J. Liang, R. P. Chen, X. Y. Wang, T. T. Liu, X. S. Wang, Y. B. Huang, R. Cao, Chem. Sci., 2017, 8, 1570-1575.

[11] G. P. Ji, Z. Z. Yang, H. Y. Zhang, Y. F. Zhao, B. Yu, Z. S. Ma, Z. M. Liu, Angew. Chem. Int. Ed., 2016, 55, 9685-9689.

[12] R. C. Luo, Y. J. Chen, Q. He, X. W. Lin, Q. H. Xu, X. H. He, W. Y. Zhang, X. T. Zhou, H. B. Ji, ChemSusChem, 2017, 10, 1-9.

[13] M. H. Liu, T. Qin, Q. Q. Zhang, C. Fang, Y. Fu, B. L. Lin, Sci. China Chem., 2015, 58, 1524-1531.

[14] C. Das Neves Gomes, O. Jacquet, C. Villiers, P. Thuéry, M. Ephritikhine, T. Cantat, Angew. Chem. Int. Ed., 2012, 51, 187-190.

[15] K. Motokura, M. Naijo, S. Yamaguchi, A. Miyaji, T. Baba, Chem. Lett., 2015, 44, 1217-1219.

[16] C. Fang, C. L. Lu, M. H. Liu, Y. L. Zhu, Y. Fu, B. L. Lin, ACS Catal,, 2016, 6, 7876-7881.

[17] H. Lv, Q. Xing, C. T. Yue, Z. Q. Lei, F. W. Li, Chem. Commun., 2016, 52, 6545-6548.

[18] L. D. Hao, Y. F. Zhao, B. Yu, Z. Z. Yang, H. Y. Zhang, B. X. Han, X. Gao, Z. M. Liu, ACS Catal, 2015, 5, 4989-4993.

[19] X. Frogneux, O. Jacquet, T. Cantat, Catal. Sci. Technol,, 2014, 4, 1529-1533.

[20] O. Jacquet, C. Das Neves Gomes, M. Ephritikhine, T. Cantat, J. Am.
Chem. Soc., 2012, 134, 2934-2937.

[21] R. C. Luo, X. T. Zhou, S. Y. Chen, Y. Li, L. Zhou, H. B. Ji, Green Chem., 2014, 16, 1496-1506.

[22] R. C. Luo, Z. Yang, W. Y. Zhang, X. T. Zhou, H. B. Ji, Sci. China Chem., 2017, 10.1007/s11426-016-0405-3.

[23] R. C. Luo, X. W. Lin, Y. J. Chen, W. Y. Zhang, X. T. Zhou, H. B. Ji, ChemSusChem, 2017, 10.1002/cssc.201601490.

[24] D. W. Tian, B. Y. Liu, Q. Y. Gan, H. R. Li, D. J. Darensbourg, ACS Catal,, 2012, 2, 2029-2035.

[25] C. X. Miao, J. Q. Wang, Y. Wu, Y. Du, L. N. He, ChemSusChem, 2008, $1,236-241$.

[26] D. W. Tian, B. Y. Liu, L. Zhang, X. Y. Wang, W. Zhang, L. N. Han, D. W. Park, J. Ind. Eng. Chem., 2012, 18, 1332-1338.

[27] T. Chang, L. L. Jin, H. W. Jing, ChemCatChem, 2009, 1, 379-383.

[28] Y. H. Li, X. J. Cui, K. W. Dong, K. Junge, M. Beller, ACS Catal., 2017, 7, 1077-1086.

[29] X.F. Liu, R. Ma, C. Qiao, H. Cao, L. N. He, Chem. Eur. J., 2016, 22, 16489-16493.

[30] S. Das, F. D. Bobbink, S. Bulut, M. Soudani, P. J. Dyson, Chem. Commun., 2016, 52, 2497-2500.

[31] J. S. Tian, C. X. Miao, J. Q. Wang, F. Cai, Y. Du, Y. Zhao, L. N. He, Green Chem., 2007, 9, 566-571.

[32] F. Castro-Gomez, G. Salassa, A. W. Kleij, C. Bo, Chem. Eur. J., 2013, $19,6289-6298$.

[33] P. P. Pescarmona, M. Taherimehr, Catal. Sci. Technol., 2012, 2, 2169-2187.

[34] T. Werner, H. Büttner, ChemSusChem, 2014, 7, 3268-3271.

[35] M. S. Liu, L. Liang, X. Li, X. X. Gao, J. M. Sun, Green Chem., 2016, 18, 2851-2863.

[36] X. Jiang, F. L. Gou, F. J. Chen, H. W. Jing, Green Chem., 2016, 18, 3567-3576.

[37] B. Dong, L. Y. Wang, S. Zhao, R. L. Ge, X. D. Song, Y. Wang, Y. A. Gao, Chem. Commun., 2016, 52, 7082-7085.

[38] M. Hulla, F. D. Bobbink, S. Das, P. J. Dyson, ChemCatChem, 2016, 8, 3338-3342.

[39] M. North, R. Pasquale, Angew. Chem. Int. Ed., 2009, 48, 2946-2948.

[40] C. Martín, G. Fiorani, A. W. Kleij, ACS Catal., 2015, 5, 1353-1370. 


\title{
季膦盐型双功能金属Salen配合物催化二氧化碳转化为高附加值化学品
}

\author{
张武英 $\mathrm{a}, \mathrm{b}$, 罗荣昌 ${ }^{\mathrm{a},}{ }^{*}$, 徐褀航 ${ }^{\mathrm{a}}$, 陈亚举 ${ }^{\mathrm{a}}$, 林小微 ${ }^{\mathrm{a}}$, 周贤太 ${ }^{\mathrm{c}}$, 纪红兵 ${ }^{\mathrm{a}, \mathrm{H}}$ \\ a中山大学化学学院, 广东省低碳化学与过程节能重点实验室, 广东广州510275 \\ b 深圳职业技术学院应用化学与生物技术学院, 广东深圳518055 \\ c中山大学化学工程与技术学院, 广东珠海519000
}

摘要: 随着全球“温室效应”和能源危机的加剧, 近几年二氧化碳作为一种丰富、无毒、廉价的碳一原料广受关注. 目前, 在 温和条件下实现二氧化碳的化学转化仍然是一个十分具有挑战性的课题, 其关键的科学问题是二氧化碳分子的有效活化. 本文发现, 在不添加任何助催化剂的条件下, 季膦盐型双功能金属Salen配合物不仅能够以有机胺、含氢硅烷和二氧化碳为 原料, 在温和条件下通过 $N$-甲酰化反应实现系列甲酰胺类衍生物的高效合成, 而且能够催化二氧化碳和环氧化合物的环加 成反应, 从而实现环状碳酸酯的宏量制备.

催化实验及动力学研究结果表明, 该双功能催化剂通过金属活性中心和卤素阴离子之间的分子内协同催化作用, 既可 利用高活性锌氢键调控含氢硅烷中的硅氢键, 又能通过高活性铝氧键激活环氧化物的三元环, 进而导致二氧化碳的方便插 入及高效活化. 譬如: 当使用 $1.0 \mathrm{~mol} \%$ 锌催化剂时, 仅加入 1 倍当量的苯硅烷, 在 $25{ }^{\circ} \mathrm{C}$ 和 $0.5 \mathrm{MPa}$ 的条件下, 反应 $6 \mathrm{~h}$ 后 $N$-甲 酰苯胺收率高达 $99 \%$; 而当使用 $0.5 \mathrm{~mol} \%$ 铝催化剂时, 在 $100{ }^{\circ} \mathrm{C}$ 和 $2.0 \mathrm{MPa}$ 的条件下反应 $2 \mathrm{~h}$, 环加成反应转化率接近 $100 \%$, 环状碳酸酯选择性可达 $99 \%$.

另外, 上述两个反应都表现出优异的底物扩展性, 具有良好的官能团相容性. 在此基础上通过构建反应动力学模型, 采用在线红外跟踪技术, 阐明了协同活化机制在二氧化碳催化转化过程中的作用原理及共性/个性规律, 丰富并发展了二 氧化碳活化的基本理论. 最后, 单组分催化剂可通过溶剂调变的方式很容易实现回收及再利用, 表现出“均相催化, 两相分 离”的特点. 循环使用五次后催化活性和选择性未见明显下降.

关键词: 二氧化碳; Salen催化剂; 季膦盐; 协同作用; 反应机理

收稿日期: 2017-01-17. 接受日期: 2017-02-28. 出版日期: 2017-04-05.

*通讯联系人. 电话: (020)84111675; 传真: (020)84113654; 电子信箱: luorongc@mail.sysu.edu.cn

\#通讯联系人. 电话: (020)84113658; 传真: (020)84113654; 电子信箱: jihb@mail.sysu.edu.cn

基金来源：国家自然科学基金(21676306, 21425627); 国家重点研发计划(2016YFA0602900); 广东省自然科学基金 (2016A030310211, 2015A030313104).

本文的英文电子版由Elsevier出版社在ScienceDirect上出版(http://www.sciencedirect.com/science/journal/18722067). 